\title{
Copyright
}

by

Bennett Ames Fallow

2012 
The Thesis Committee for Bennett Ames Fallow

Certifies that this is the approved version of the following thesis:

\section{Influence of Skin Type and Wavelength on Light Wave Reflectance}

\section{APPROVED BY SUPERVISING COMMITTEE:}

Supervisor:

Hirofumi Tanaka

Matthew Brothers 
Influence of Skin Type and wavelength on Light Wave Reflectance

by

\title{
Bennett Ames Fallow, B.S.
}

\author{
Thesis \\ Presented to the Faculty of the Graduate School of \\ The University of Texas at Austin \\ in Partial Fulfillment \\ of the Requirements \\ for the Degree of \\ Master of Science in Kinesiology
}

The University of Texas at Austin

May 2012 


\section{Dedication}

In dedication to my family, friends, and Jessie for whom I could of not done this without. Their constant support, faith and encouragement provided me with the strength and passion that allowed me to pursue my dreams. They are my foundation and worked just as hard as I did being here for me. Thank you with all my heart and love. 


\section{Acknowledgements}

A very special thanks to Dr. Tanaka my primary investigator and advisor, whom kept me on track and taught me that research, is more than just knowledge; it is a complete pursuit and dedication. His ability to drive and teach were great examples and helped me grow as a graduate student and researcher but also as a person. Thanks to Dr. Brothers for being my second reader and providing a second set of eyes to my ideas. Special thanks to my lab mates of the Cardiovascular Aging Research Lab whose help and commodore came into use and appreciation every day. Thanks to Patty Coffman, her super organizational talents and up beat optimism on a daily basis were a great welcoming and who took time out of her day no matter what to help those disheveled and stressed graduate students. Thank you to OMRON healthcare company for providing the prototype device, providing assistance with data collection and troubleshooting throughout testing. 


\begin{abstract}
Influence of skin type and wavelength on light wave reflectance
\end{abstract}

\author{
Bennett Ames Fallow M.S.Kin. \\ The University of Texas at Austin, 2012
}

Supervisor: Hirofumi Tanaka

Heart rate monitoring (HRM) is an essential tool for monitoring physical activity and as a diagnostic tool in the clinical setting. The ability to monitor heart rate gives users and clinicians vital information about the current condition of the cardiovascular system before, during, and after exercise. However, HRM requires a telemetric chest strap, and comfort, transmission and fit can become problems with the chest strap. New technology using photoplethysmography (PPG) has emerged recently to provide the possibility of HRM without a telemetric chest strap during exercise. The aim of this study was to determine if a new device could detect heart rate over a broad range of skin types (I-V), and whether what wavelength would be most suitable for detecting the signals. A light emitting diode (LED) based PPG system was used to determine heart rate by change in pulsatile blood flow on 22 apparently healthy individuals (11 male and 11 female, 20-59 years old) of varying skin type. Skin type was classified according to a questionnaire in combination with digital photographs with a skin type chart. Each subject was exposed to four different wavelengths $(470 \mathrm{~nm}, 520 \mathrm{~nm}, 630 \mathrm{~nm}$, and 880 $\mathrm{nm}$ ) and multiple trials were conducted on each wavelength. Heart rate detection was 
represented by modulation of the incident light wave and normalized by saturation into a pulsatile waveform represented as modulation average. The 520nm wavelength classified as visible green light provided a significantly greater $(\mathrm{p}<0.001)$ ability to detect heart rate. Increasing levels of melanin, or darker skin type (Type V) showed decreased modulation however this trend was not significant $(\mathrm{p}<0.067)$. There was no significant interaction between the wavelength of light and the skin type. In conclusion, a PPG based device can detect heart rate across skin types and use of a green light wavelength provides an even greater resolution. 


\section{Table of Contents}

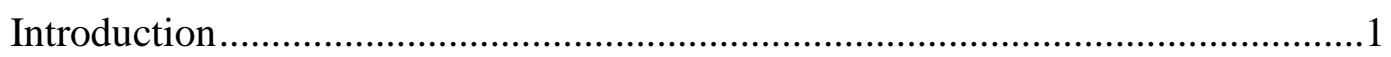

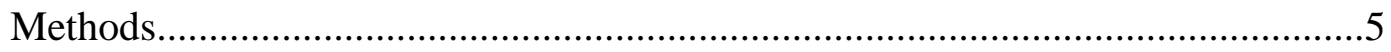

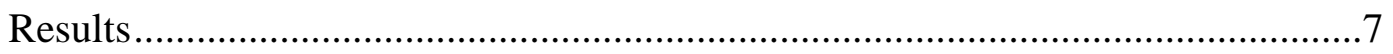

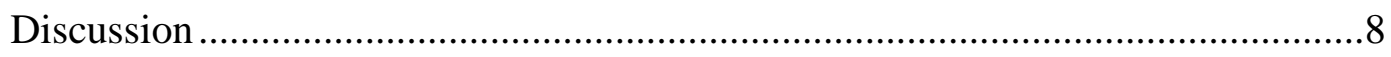

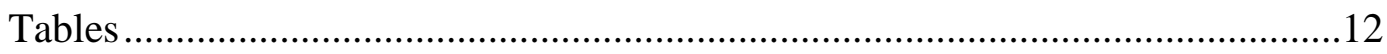

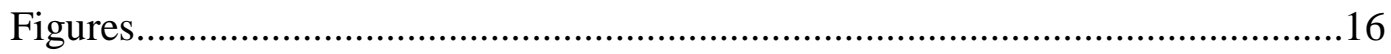

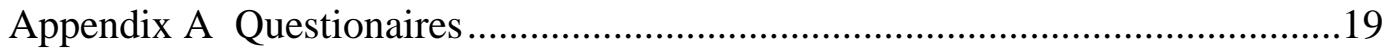

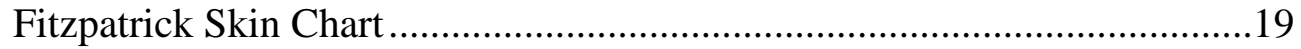

Health History Questionaire ...............................................................21

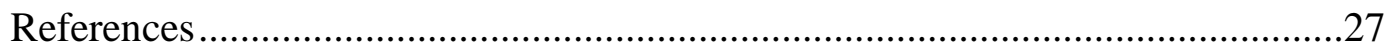




\section{List of Tables}

Table 1: $\quad$ Selected subject characteristics .....................................................11

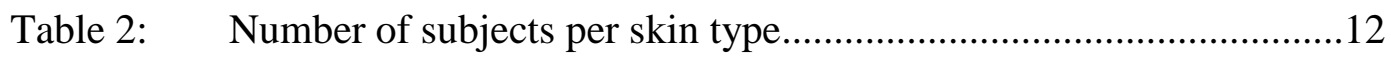

Table 3: Wavelength and skin type interaction at rest ...............................13

Table 4: Wavelength and skin type interaction signal during exercise...........14 


\section{List of Figures}

Figure 1: Combined modulation for all skin types for each wavelength .........15

Figure 2: Differences in modulation between skin types across wavelengths

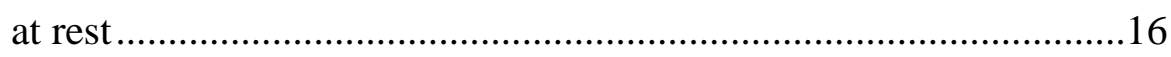

Figure 3: Differences in modulation between skin types during exercise........17 


\section{Introduction}

Exercise is an integral part of reducing the risks of cardiovascular disease and improving quality of life. ${ }^{42}$ Aerobic exercise involves large muscle group movement in a coordinated and purposeful fashion in the intention of stressing the cardiovascular system and causing chronic and beneficial adaptation over time. ${ }^{4,11,21}$ An important requirement for performing and prescribing physical activity and exercise is to ensure that the dose and intensity of exercise are sufficient to elicit a response that benefits the individual or group. ${ }^{1,21,27,30,42,47}$ By assuming the linearity of heart rate and oxygen consumption, heart rate provides a window into the cardiovascular stress being placed on the body during exercise. ${ }^{1,17,34}$ HRM are convenient means to ensure that exercise is performed at a proper intensity. ${ }^{10,11,12,14,17,21}$ In particular, endurance athletes use HRM as a key component in training to ensure proper adaptation and protect against overexertion and overtraining. ${ }^{1,11}$

Although heart rate monitoring provides a practical approach for training, exercise and clinical and research applications, traditional HRM faces several limitations.

${ }^{30}$ Most HRM require a chest strap connected to the exercisers skin in order to obtain a signal based on electrocardiogram (ECG) technology. Transmission problems can arise due to conflicting radio signals or frequencies or because of multiple monitors in proximity. The strap is also dependent on moisture and sweat to maintain conductivity on the skin. Many exercisers also experience problems properly adjusting the strap; this 
obstacle is intensified in obese individuals who may struggle to find bands that fit. The strap must also be kept quite tight, prompting some exercisers to report discomfort during testing or training; this factor compounds the challenge of wearing the monitor for an extended duration. $^{30}$

A solution to the issues presented in HRM would be a watch-based unit that measures heart rate locally on the wrist that eliminates the use of a chest strap. Using photoplethysmography (PPG), the watch-based unit could monitor changes in arterial blood volume to derive pulse rate by the change in volume upon systolic/diastolic fluctuations of light wave reflectance attenuation. PPG also measures local perfusion and vessel depth through the same light wave reflectance. A light emitting diode (LED) transmits light, while a photoreceptor placed adjacently receives the reflected light. Changes in the incident to reflected wavelength are then calculated and used to determine the physiological phenomena below; at the same time, known wavelengths are able to reach the underlying vasculature. ${ }^{6,16,49,50}$

The main concern with PPG technology for detection of pulse rate is related to the melanin concentration of the skin and its related pigmenting of skin. ${ }^{3,20,50}$ Melanin is known to be highly absorbent to light, and thereby attenuating the incident light wavelength. ${ }^{9,20}$ The level of skin in which melanin is found is the epidermal layer. ${ }^{9}$ There is no blood supply to the epidermal layer and it relies solely on diffusion of oxygen from deeper vessels. ${ }^{9}$ The target for a PPG device is sub-epidermal and thus should not modify the overall shape of the modulation waveform. ${ }^{9}$ It is therefore suggested that a weak reflected light due to dark pigmentation can be compensated for by using a stronger 
light source, without compromising the signal to noise ratio. ${ }^{9}$ Another important aspect is the artifact that motion and physiological changes can create. ${ }^{3,9,23,32}$ This is represented by the signal to noise ratio. The determination of the signal to noise ratio involves taking the AC current during exercise and comparing it to $\mathrm{AC}$ at rest. The greater the value of the signal compared to the noise, the greater the detection of pulse rate during activity. ${ }^{20}$

As the PPG signal is dependent on the energy associated with its wavelength, different wavelengths are able to penetrate the tissue to varying depths based on their energy level, and provide various levels of pulse detection from different sources. ${ }^{3,9,23,50}$ In choosing a proper wavelength the target must be appropriately selected in combination with the wavelength. It is therefore critical that the device penetrate deep enough to provide detection of arterial vessels in order to determine the pulsatile changes in associated volume between systole and diastole. , $^{3,8,9,9,16,20,23,25,26}$

In the present study, the interaction between various light wavelengths and skin type was investigated at rest and during exercise. We hypothesized that certain wavelengths of light would provide better light reflectance across skin types represented by a greater peak in modulation. We also hypothesized that shorter wavelengths would provide a better signal to noise ratio indicating improved detection during exercise. 


\section{Methods}

Subjects. A total of 22 apparently healthy adults (11 males/ 11 females) aged 2059 years were recruited from the University of Texas at Austin and surrounding community (Table 1). The Human Research Committee reviewed and approved all procedures, and written informed consent was obtained from all subjects. Subjects with varying skin types were recruited to assess the influence of skin type on wave reflectance (Table 2).

Experimental Protocol. After arrival, subjects were kept in a quiet laboratory room in a seated position for $15 \mathrm{~min}$ and their blood pressure was taken. A photograph of each subject’s forearm was taken against a color chart for skin pigmentation. Subjects were then classified into four different skin type groups ranging from type I to type V. LED sensors from the PPG device (OMROM Kyoto, Japan) were placed on the radial artery and the back of the forearm approximately 4 centimeters from the wrist joint. An accelerometer was then strapped to detect movement and eliminate environmental light. Pressure of the strap that the LED sensors were attached was standardized by a spring gauge. Upon the proper placement of the sensor, the signal was verified on screen before the tests were initiated. Four different wavelengths of light were used in assessment of heart rate detection (Green 520 nm, Red 630 nm, Infrared 880 nm, and Blue 470 nm). Skin types I and II were combined into one group. Wavelength order was randomly chosen from a randomized number generator. 
Three different intensities of each wavelength were used for each site. The protocol involved the subject keeping the forearm stable atop a desk with his or her fist relaxed, then performing a flexion/extension of the arm in a curling motion for 10 seconds, and finally grasping a dynometer and applying 5 to 10 newton meters (NM) of force for 10 seconds.

Once the light has been transmitted and reflected, two different waveforms are created, an alternating current (AC) and direct current (DC). ${ }^{3,20,23}$ The AC pulsation refers to the pulsatile change in blood flow between systole and diastole from the absorption of hemoglobin, where the DC current is composed of the saturation of the skin, surrounding tissue, and average blood volume. ${ }^{3,9,20,23,26}$ Normalized modulation level is calculated as the AC/DC component and represents the change in flow over the underlying constant state of flow or perfusion.,9,23

Skin type was measured based on a subjective questionnaire that has been established in the literature for skin type determination. This skin typing was then compared to a photograph of each subjects forearm, whereupon any discrepancies between these two were adjusted towards the photograph and actual pigmentation, not the pigmentations behavior defined in the Fitzpatrick skin type chart.

Both AC and DC currents were measured during each trial. Modulation is the average change between peaks and valleys in the AC component or the constant rate of the DC component. Taking the AC current over the DC current provides normalized modulation and represents the effect of the status of the tissue by the change in blood 
flow within the artery. ${ }^{2,3,9,20}$ For the exercise section of the trial, the AC during exercise was taken over the AC rest to determine a signal to noise ratio for each wavelength.

\section{Statistical Analysis}

Two-way analysis of variance (ANOVA) (wavelength x skin type) was performed for both side of the forearm. The entire trial duration for each section was averaged and used separately for analysis (10 seconds). Tukeys HSD post hoc was performed and used to determine where the significance occurred after providing a significant finding from the two-way ANOVA. A three-way ANOVA was also conducted to determine if intensity of wavelengths contributed to influencing wavelength. A difference in intensity of each wavelength was not demonstrated, and therefore intensities were combined for each wavelength. Two-way ANOVA was run for the signal to noise ratio, a main effect was found and an interaction. Pair wise comparisons were then made to determine where the interaction occurred. All statistical analyses were performed using IBM SPSS Statistics 20.0 (IBM Corporation Armonk, NY). Significance was set a priori at the $\mathrm{p}<0.05$ level. All data are expressed as means \pm SD. 


\section{Results}

Skin types ranged from type I (Very pale) to type V (Dark). Differences between levels of intensity for each wavelength were minimal, and a three-way AVNOVA was run to determine any significance or interaction. All intensities were thereby combined for each wavelength for each subject. There was a trend towards skin type influencing modulation, ( $<<0.064)$, but it did not reach statistical significance. There was no interaction between skin type and wavelength on light reflectance during rest.

In the resting condition, the green light wavelength $(520 \mathrm{~nm})$ provided greater peak normalized modulation of blood regardless of skin type. The back side of the forearm also resulted in green light being significantly greater in modulation. Type $\mathrm{V}$ skin type was significantly lower in peak modulation than all other skin types on the back of the forearm. Green light was significantly $(\mathrm{p}<0.001)$ different from the other wavelengths in normalized modulation (Table 3) and displayed the greatest peak among all wavelengths (Figure 1). Post hoc comparisons for the exercise simulation demonstrated that both blue and green wavelengths provide displayed detection and improved signal to noise ratio than red or infrared wavelengths $(p<0.001)$. There were differences in signal to noise ratio among skin types during exercise simulation. (I \& II vs. IV, III vs. IV, and IV vs. V , all ( $<<0.01)$;(Table 4)). A significant interaction was found between wavelength and skin type during the exercise portion of the protocol $\mathrm{p}<0.029$. Pair wise comparisons were then done to determine where the interaction occurred. 


\section{Discussion}

The intent of the present study was to determine the influence of skin type and wavelength on light reflectance for heart rate detection. Heart rate was detectable across all skin types represented by the detection of an AC modulatory pulsatile waveform. The AC waveform was averaged as the peak and the modulation from that peak was then recorded and reported as AC modulation. This modulation was recorded as the pulsatile waveform and confirmed from visual inspection from the software. Green light (520 $\mathrm{nm}$ ) was found to produce greater modulation than other wavelengths at rest. Exercising signal to noise ratio was greatest for blue and green wavelengths. Each subject's pulsatile waveform was acquired before recording modulations. To the best of my knowledge, this is the first study to examine the effect of skin type on light wave reflectance for heart rate detection at rest and during exercise using four different wavelengths of light from a LED PPG device.

The green wavelength was able to detect the pulsatile blood volume changes better than any other wavelength, as demonstrated by a significantly greater peak in normalized modulation for both radial arterial side and the back of forearm. The shorter the wavelength of light, the less distance the incident light can travel, which also results in faster reflectance of the incident wavelength. This facilitates a more robust resistance to artifact or noise but shortening the duration of total time..$^{9,23,32,49,50}$ This was represented in the green and blue wavelengths producing significantly greater 
signal/noise ratios compared with that of red and infrared for the same and different skin types. Overall the green wavelength was significantly different across varying skin types compared to all other wavelengths. Blood during systole has a greater volume and creates a greater absorbance of light compared with that of diastole. Hemoglobin plays a major role on light absorption especially at the lower wavelengths. ${ }^{44,50}$ The sensor then interprets the inverse of the absorption in relation to blood volume in the tissue. ${ }^{49}$ By detecting the change in the fluctuation of hemoglobin in the radial artery, a PPG-based device is able to determine pulse rate. This is represented by the AC current change. The DC current represents local perfusion and saturation along with light absorption of the tissue itself. If the DC current changes (due to different skin types, different subjects) this will result in a difference in pulse height and such differences must be accounted for in the signal processing. ${ }^{2,9,43}$ The use of a normalized modulation allows for detection across the spectrum of skin types and physiological phenomena. It also allows for comparison across skin types to interpret any type of interaction. ${ }^{2,3,6}$

There was no significant differences in modulation between the interaction of skin type at rest. While it is known that the size of light reflectance should change dependent on wavelength through varying skin types, the shape, or detection overall shouldn't be affected. ${ }^{9}$ The level at which pigmentation from melanin occurs in the skin is the epidermis. Because arterial blood resides in sub-epidermal layers, the overall detection of pulsatile flow should not be greatly affected. The current study reflected this by demonstrating that each wavelength was able to find blood flow for each subject regardless of skin type yet produced differences in the level of modulation. By 
normalizing the modulation, and using wavelengths that have been found to better determine pulsatile blood flow, our present study demonstrated the practical application of a PPG device may be a promising technique as a heart rate monitor., ${ }^{9,16,20,26,32}$ To our knowledge this is the first study to examine light wavelength reflectance and skin type influence during both rest and exercise.

While the training effect and intensity are critical components in exercise and training, another key point HRM provides is caloric expenditure vital for calculations to determine the caloric intake necessary for weight loss. Because of the linear link to oxygen consumption, HRM can furnish insight into energy expenditure and provides a cost-effective method for calculating total caloric rates.

Even as the paradigm for HRM seems to have been established in radio telemetric units, the PPG has the potential to offer much greater resolution than mere heart rate in the future. PPG can also provide such variables as pulse wave velocity, a measure of arterial stiffening and vascular aging, hemodynamic stress through augmentation of the waveforms, and heart rate variability, a maker for autonomic health. In the future, this device can extend its clinical utility by equipping these extra features.

A limitation to the current study was the relatively small sample size. Groups were not equal in terms of number of subjects per group.

In conclusion photoplethysmography has the ability to detect pulse rate through the use of light wave reflection. In our study, a wavelength of $520 \mathrm{~nm}$ corresponding to green visible light produced the best modulation at rest. There was a trend towards skin type having a significant effect yet no interaction was present during rest. Exercise 
elucidated a significant interaction between wavelength and skin type at the shorter wavelengths for signal/noise ratio. This stresses the need for shorter wavelengths to be used in detection of heart rate through light reflectance. PPG heart rate monitoring therefore presents both a viable step and a logical one in better resolution for monitoring the heart rate. 
Table 1. Selected subject characteristics

\begin{tabular}{llc}
\hline N, male/female & \multicolumn{2}{c}{$11 / 11$} \\
Age, yrs & 31 & \pm 12 \\
Height, cm & 172 & \pm 8 \\
Body Mass, kg & 72 & \pm 14 \\
BMI, kg/m ${ }^{2}$ & 24 & \pm 3 \\
Systolic BP, mmHg & 123 & \pm 14 \\
Diastolic BP, mmHg & 73 & \pm 9 \\
Mean BP, mmHg & 91 & \pm 9 \\
\hline
\end{tabular}

Data are mean \pm SD. BMI = body mass index, $\mathrm{BP}=$ blood pressure. 
Table 2. The number of subjects per skin type

\begin{tabular}{ll} 
Skin Type & N \\
\hline Type I and II & 8 \\
Type III & 5 \\
Type IV & 4 \\
Type V & 6 \\
\hline
\end{tabular}


Table 3. Wavelength and skin type interaction at rest

\begin{tabular}{lllll}
\hline & \multicolumn{1}{c}{$470 \mathrm{~nm}$} & \multicolumn{1}{c}{$520 \mathrm{~nm}$} & $630 \mathrm{~nm}$ & \multicolumn{1}{c}{$880 \mathrm{~nm}$} \\
\hline Type I and II & $36.4 \pm 16.1$ & $81.2 \pm 25.2^{*}$ & $19.4 \pm 10.9$ & $23.0 \pm 17.6$ \\
Type III & $37.2 \pm 11.7$ & $69.9 \pm 32.3^{*}$ & $22.7 \pm 14.8$ & $32.9 \pm 15.6$ \\
Type IV & $31.8 \pm 10.0$ & $77.7 \pm 22.7^{*}$ & $34.6 \pm 12.3$ & $34.9 \pm 25.8$ \\
Type V & $23.6 \pm 4.4$ & $49.0 \pm 46.8^{*}$ & $22.5 \pm 5.7$ & $18.1 \pm 7.7$ \\
\hline
\end{tabular}

Data are expressed as mean modulation x $1000 \pm$ SD. ${ }^{*} \mathrm{p}<0.001$ 
Table 4. Wavelength and Skin Type Interaction signal to noise ratio during exercise

\begin{tabular}{|c|c|c|c|c|}
\hline & $470 \mathrm{~nm}$ & $520 \mathrm{~nm}$ & $630 \mathrm{~nm}$ & $880 \mathrm{~nm}$ \\
\hline Type I and II & $40.7 \pm 8.5$ & $31.6 \pm 8.5^{*}$ & $6.3 \pm 8.5$ & $8.4 \pm 9.3$ \\
\hline Type III & $77.5 \pm 9.3 \ddagger$ & $46.9 \pm 8.5$ & $11.6 \pm 8.5 \neq$ & $25.5 \pm 7.9 \neq$ \\
\hline Type IV & $56.9 \pm 10.4$ & $84.3 \pm 10.4^{* \dagger}$ & $18.4 \pm 10.4 \dagger$ & $16.6 \pm 10.4 \dagger$ \\
\hline Type V & $33.1 \pm 8.5$ & $16.6 \pm 8.5^{*}$ & $11.0 \pm 8.5$ & $9.5 \pm 8.5$ \\
\hline \multicolumn{5}{|c|}{$\begin{array}{l}\text { Data are expressed as mean modulation x } 100 \pm \text { SD. }{ }^{*} \mathrm{p}<0.05 \text { for same wavelength } \\
\text { between skin types for } 520 \mathrm{~nm} \text { of Type I and II compared to } 630 \mathrm{~nm} \text { and } 880 \mathrm{~nm} \text {. } \\
{ }^{\dagger} \mathrm{p}<0.05 \text { between wavelength for same skin type for } 520 \mathrm{~nm} \text { compared to } 630 \mathrm{~nm} \\
\text { and } 880 \mathrm{~nm} . \neq \mathrm{p}<0.05 \text { between wavelengths for same skin type wavelength } 470 \mathrm{~nm} \\
\text { compared to } 630 \mathrm{~nm} \text { and } 880 \mathrm{~nm} \text {. }\end{array}$} \\
\hline
\end{tabular}


Figure 1: Combined mean modulation for all skin types $(\mathrm{I}-\mathrm{V})$ for each wavelength

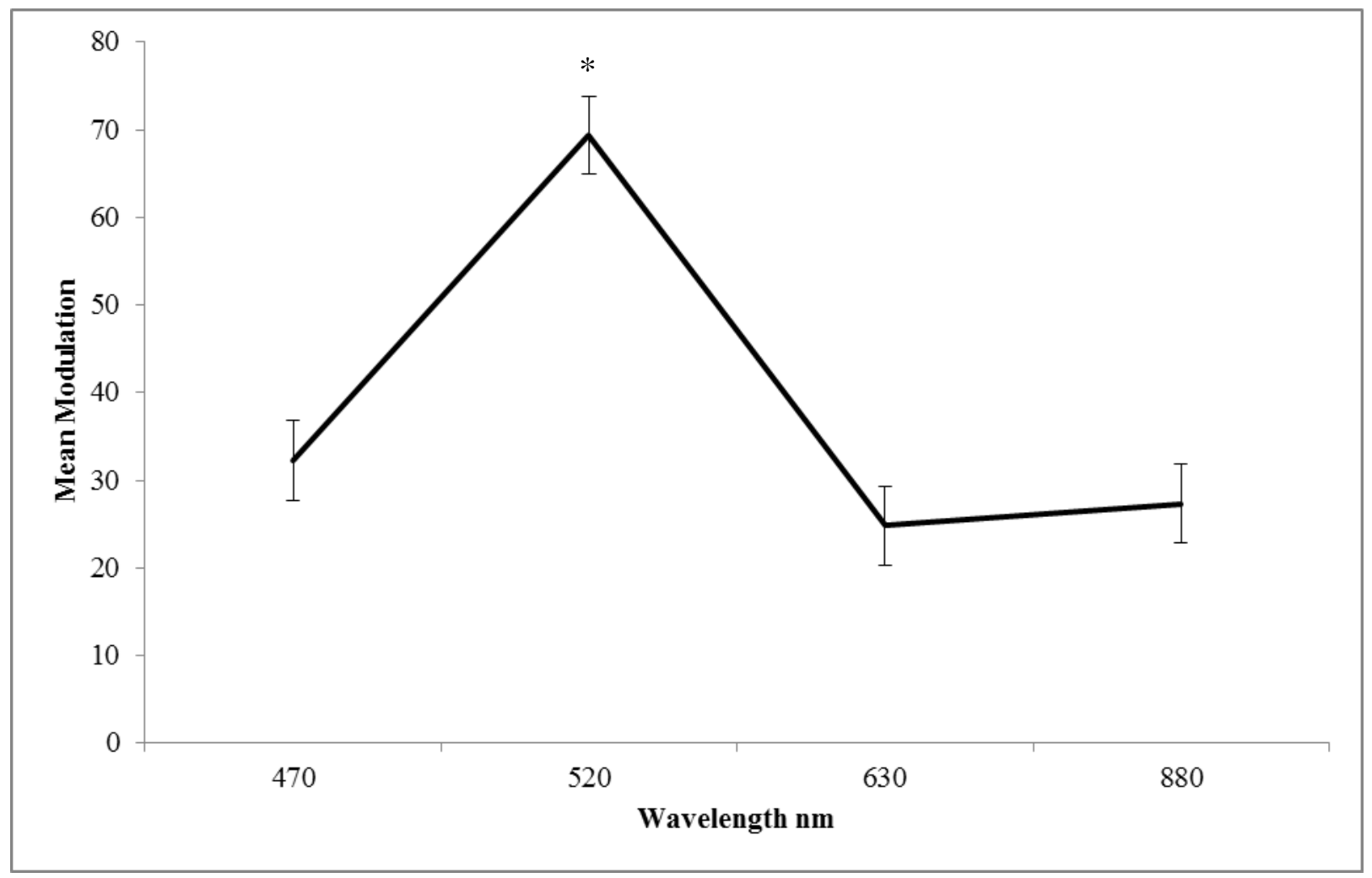

${ }^{*} \mathbf{p}<0.001$ for $520 \mathrm{~nm}$ (green) compared to $470 \mathrm{~nm}, 630 \mathrm{~nm}, 880 \mathrm{~nm}$ 
Figure 2: Differences in modulation between skin types across wavelengths at rest

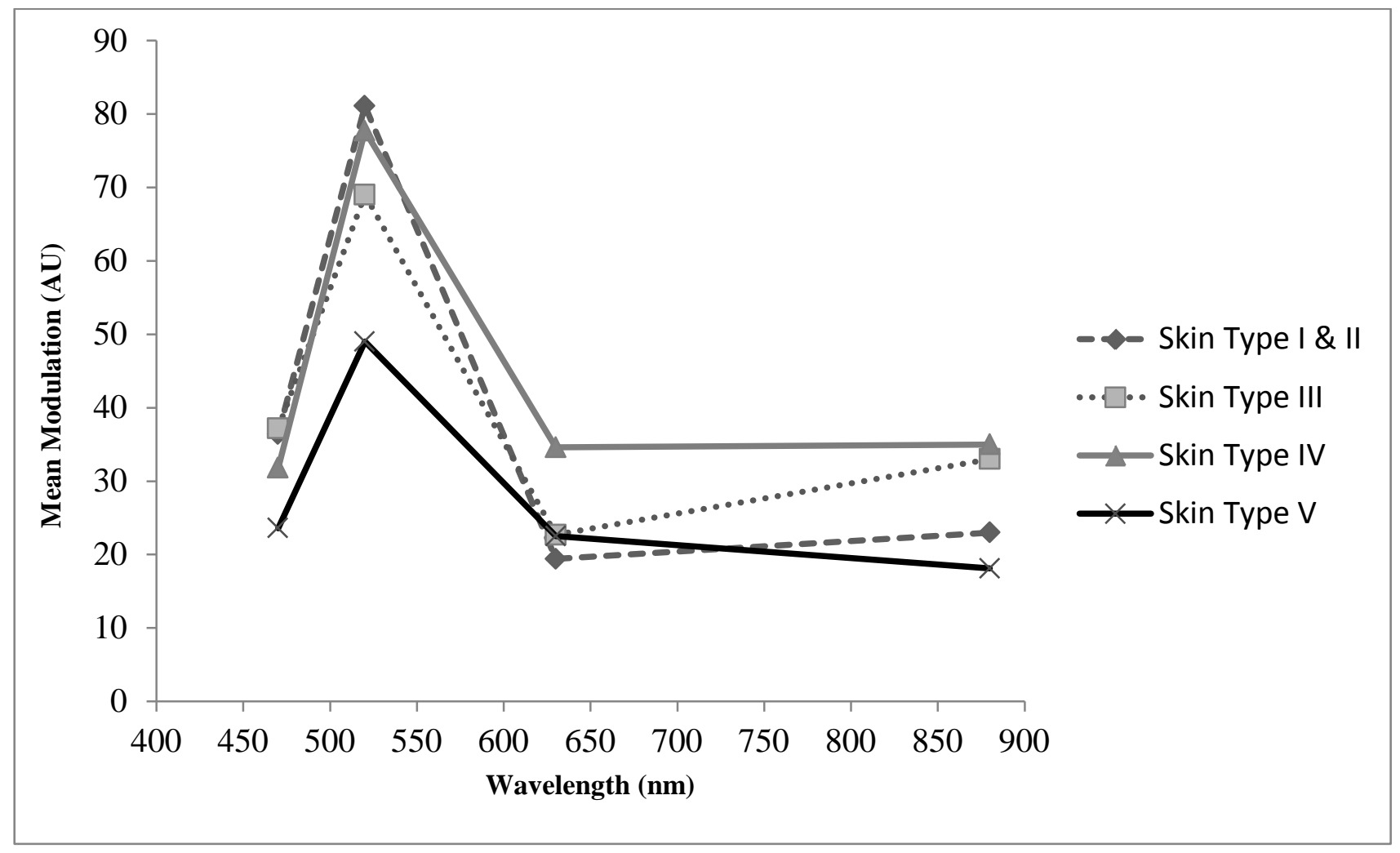


Figure 3: Differences in modulation between skin types during exercise

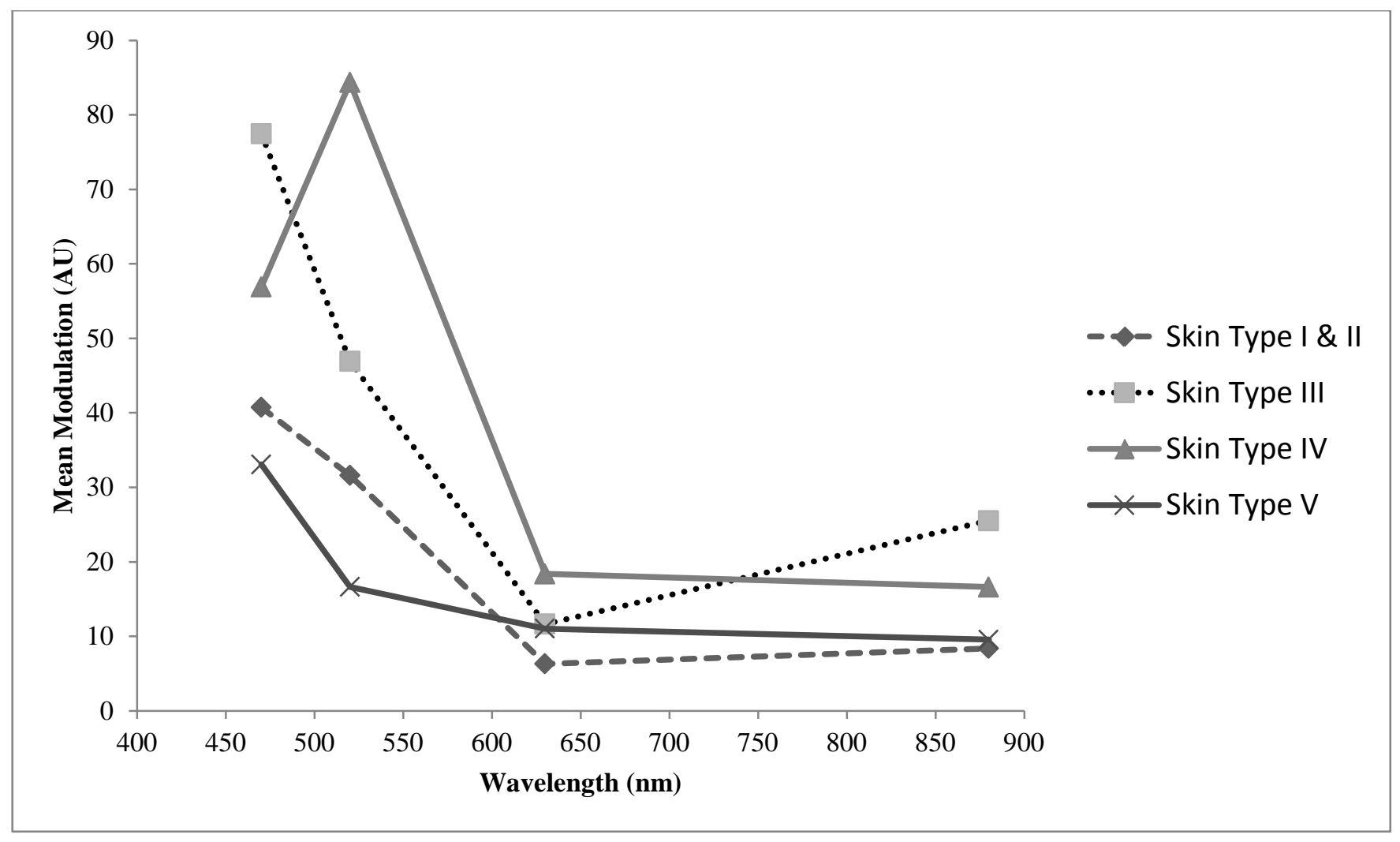




\section{The Fitzpatrick Skin-Type Chart}

You can use this skin-type chart for self-assessment, by adding up the score for each of the questions you've answered. At the end there is a scale providing a range for each of the six skin-type categories. Following the scale is an explanation of each of the skin types. You can quickly and easily determine which skin type you are.

\section{Genetic Disposition}

\begin{tabular}{|l|c||c|c||c|c|}
\hline Score & $\mathbf{0}$ & $\mathbf{1}$ & $\mathbf{2}$ & $\mathbf{3}$ & $\mathbf{4}$ \\
\hline What is the colour of your eyes? & $\begin{array}{c}\text { Light blue, } \\
\text { Grey, Green }\end{array}$ & $\begin{array}{c}\text { Blue, Grey or } \\
\text { Green }\end{array}$ & Blue & $\begin{array}{c}\text { Dark } \\
\text { Brown }\end{array}$ & $\begin{array}{c}\text { Brownish } \\
\text { Black }\end{array}$ \\
\hline $\begin{array}{l}\text { What is the natural colour of } \\
\text { your hair? }\end{array}$ & Sandy Red & Blond & $\begin{array}{r}\text { Chestnut/Dark } \\
\text { Blond }\end{array}$ & $\begin{array}{c}\text { Dark } \\
\text { Brown }\end{array}$ & Black \\
\hline $\begin{array}{l}\text { What is the colour of your skin } \\
\text { (non exposed areas)? }\end{array}$ & Reddish & Very Pale & $\begin{array}{c}\text { Pale with Beige } \\
\text { tint }\end{array}$ & $\begin{array}{c}\text { Light } \\
\text { Brown }\end{array}$ & Dark Brown \\
\hline $\begin{array}{l}\text { Do you have freckles on } \\
\text { unexposed areas? }\end{array}$ & Many & Several & Few & Incidental & none \\
\hline
\end{tabular}

Total score for Genetic Disposition:

\section{Reaction to Sun Exposure}

\begin{tabular}{|c|c|c|c|c|c|}
\hline Score & 0 & 1 & 2 & 3 & 4 \\
\hline $\begin{array}{l}\text { What happens when you } \\
\text { stay in the sun too long? }\end{array}$ & $\begin{array}{c}\text { Painful redness, } \\
\text { blistering, } \\
\text { peeling } \\
\end{array}$ & $\begin{array}{c}\text { Blistering } \\
\text { followed by } \\
\text { peeling } \\
\end{array}$ & $\begin{array}{l}\text { Burns sometimes } \\
\text { followed by peeling }\end{array}$ & $\begin{array}{l}\text { Rare } \\
\text { burns }\end{array}$ & $\begin{array}{l}\text { Never had } \\
\text { burns }\end{array}$ \\
\hline $\begin{array}{l}\text { To What degree do you } \\
\text { turn brown? }\end{array}$ & $\begin{array}{c}\text { Hardly or not at } \\
\text { all }\end{array}$ & Light colour tan & Reasonable tan & $\begin{array}{c}\text { Tan very } \\
\text { easy }\end{array}$ & $\begin{array}{l}\text { Turn dark } \\
\text { brown } \\
\text { quickly }\end{array}$ \\
\hline $\begin{array}{l}\text { Do you turn brown within } \\
\text { several hours after sun } \\
\text { exposure? }\end{array}$ & Never & Seldom & Sometimes & Often & Always \\
\hline $\begin{array}{l}\text { How does your face react } \\
\text { to the sun? }\end{array}$ & Very sensitive & Sensitive & Normal & $\begin{array}{c}\text { Very } \\
\text { resistant }\end{array}$ & $\begin{array}{c}\text { Never had a } \\
\text { problem }\end{array}$ \\
\hline
\end{tabular}

Total score for Reaction to Sun Exposure:

\section{Tanning Habits}

\begin{tabular}{|c|c|c|c|c|c|}
\hline Score & 0 & 1 & 2 & 3 & 4 \\
\hline $\begin{array}{l}\text { When did you last expose your body to } \\
\text { sun (or artificial sunlamp/tanning } \\
\text { cream)? }\end{array}$ & $\begin{array}{l}\text { More than } 3 \\
\text { months ago }\end{array}$ & $\begin{array}{c}2-3 \\
\text { months } \\
\text { ago }\end{array}$ & $\begin{array}{c}\text { 1-2 months } \\
\text { ago }\end{array}$ & $\begin{array}{l}\text { Less than a } \\
\text { month ago }\end{array}$ & $\begin{array}{l}\text { Less than } 2 \\
\text { weeks ago }\end{array}$ \\
\hline $\begin{array}{l}\text { Did you expose the area to be treated to } \\
\text { the sun? }\end{array}$ & Never & $\begin{array}{l}\text { Hardly } \\
\text { ever }\end{array}$ & Sometimes & Often & Always \\
\hline
\end{tabular}

Total score for Tanning Habits: 
Add up the total scores for each of the three sections for your Skin Type Score.

\section{Skin Type Score - Fitzpatrick Skin Type}

\begin{tabular}{|l||c||}
\hline $0-7$ & I \\
\hline $8-16$ & II \\
\hline $17-25$ & III \\
\hline $25-30$ & IV \\
\hline over 30 & V -VII \\
\hline
\end{tabular}

TYPE 1: Highly sensitive, always burns, never tans. Example: Red hair with freckles TYPE 2: Very sun sensitive, burns easily, tans minimally. Example: Fair skinned, fair haired Caucasians

TYPE 3: Sun sensitive skin, sometimes burns, slowly tans to light brown. Example: Darker Caucasians.

TYPE 4: Minimally sun sensitive, burns minimally, always tans to moderate brown. Example: Mediterranian type Caucasians, some Hispanics.

TYPE 5: Sun insensitive skin, rarely burns, tans well. Example: Some Hispanics, some Blacks

TYPE 6: Sun insensitive, never burns, deeply pigmented. Example: Darker Blacks. 


\section{Health Research Questionnaire \\ Cardiovascular Aging Research Laboratory \\ University of Texas at Austin}

\section{Personal Information}

Today's Date

Phone Number

Date of Birth

Who is your physician?

In case of emergency, contact
Please print your name Email

Age Sex

Male

Female Phone Phone

Please circle the highest grade in school you have completed:

$\begin{array}{lllllllll}\text { Elementary school } & 1 & 2 & 3 & 4 & 5 & 6 & 7 & 8\end{array}$

$\begin{array}{lllll}\text { High school } & 9 & 10 & 11 & 12\end{array}$

$\begin{array}{lllllllll}\text { College/Post Grad } & 13 & 14 & 15 & 16 & 17 & 18 & 19 & 20+\end{array}$

What is your martial status? $\square$ Single $\square$ Married; $\square$ Widowed $\square$ Divorced;

Separated

Ethnic Background: $\quad \square$ Hispanic or Latino $\square$ Not Hispanic or Latino

Race:

$\square$ White

American Indian/Alaskan Native

$\square$ Pacific Islander

Black or African American $\quad \square$ Asian

\section{Symptoms or Signs Suggestive of Disease}

Check appropriate box:

Yes No

1. Have you experienced unusual pain or discomfort in your check, neck, jaw, arms or other areas that may be due to heart problems?

2. Have you experienced unusual fatigue or shortness of breath at rest, during usual activities, or during mild-to-moderate exercise (e.g., climbing stairs, carrying groceries, brisk walking, cycling)?

3. When you stand up, or sometimes during the night while you are sleeping, do you have difficulty breathing?

4. Do you lose your balance because of dizziness or do you ever lose consciousness?

5. Do you suffer from swelling of the ankles (ankle edema)?

6. Have you experienced an unusual and rapid throbbing or fluttering of the heart?

7. Have you experienced severe pain in your leg muscles during walking?

8. Has a doctor told you that you have a heart murmur? 


\section{Chronic Disease Risk Factors}

Check appropriate box:

\section{Yes No}

9a. Are you a male over age 45 years or a female over age 55 years?

b. Are you a female who has experienced premature menopause?

c. If you answered "yes" to 9b, are you on estrogen replacement therapy?

10. Has your father or brother had a heart attack or died suddenly of heart disease before the age of 55; has your mother or sister experienced these heart problems before the age of 65?

Yes No

11. Are you a current cigarette smoker?

12. Has a doctor told you that you have high blood pressure (more than 140/90 mm Hg) or a heart condition?

13. Is your total serum cholesterol greater than $200 \mathrm{mg} / \mathrm{dl}$, or has a doctor told you that your cholesterol is at a high risk-level?

14. Do you have diabetes mellitus?

15. Are you physically inactive and sedentary (little physical activity on the job or during leisure time)?

16. Do you have a bone or joint problem that could be made worse by a change in your physical activity?

17. During the past year, would you say that you have experienced enough stress, strain, and pressure to have a significant effect on your health?

18. Do you eat foods nearly every day that are high in fat and cholesterol such as fatty meats, cheese, fried foods, butter, whole milk, or eggs?

19. Do you weigh 30 or more pounds than you should?

20. Do you know of any other reason you should not do physical activity?

\section{Medical History}

21. Please check which of the following conditions you have had or now have. Also check medical conditions in your family (father, mother, brother(s), or sister(s)). Check as many as apply.

\section{Self Family Medical Condition}

Coronary heart disease, heart attack; by-pass surgery

Arrhythmias

Angina

High blood pressure

Peripheral vascular disease

\section{Self Family Medical Condition}

Major injury/fracture to foot, leg, knee

Major injury to back or neck

Major injury/fracture to hip or shoulder

Rheumatoid Arthritis

Osteoarthritis 
Phlebitis or emboli

Other heart problems

Stroke

Asthma

Bronchitis

COPD (emphysema)

Lung cancer

Breast cancer

Prostate cancer

Skin cancer

Colorectal cancer

Other cancer. Specify:

Gallstones/gallbladder

disease

Liver disease (cirrhosis)

Hepatitis
Gout

Osteoporosis

Fibromyalgia

Diabetes mellitus

Kidney disease

Cataracts

Glaucoma

Hearing loss

Depression

Anxiety, phobias

Eating disorders

Sleeping problems

Substance abuse problems (alcohol, other drugs, etc.)

Chronic Fatigue Syndrome

Thyroid problems 


\section{Self Family Medical Condition}

Anemia (low iron)

Stomach/duodenal ulcer

Rectal growth or bleeding

Crohne's disease

Irritable bowel syndrome

Marfan’s syndrome

\section{Self Family Medical Condition}

$\square \quad \square \quad$ Hysterectomy

Problems with menstruation

Post-menopausal (date:

Raynaud's disease

Allergies

Any other health problems. Please specify and include information on any recent illnesses, hospitalizations, or surgical procedures.

22. Please check any of the following medications you take regularly and give the name of the medication.

\section{Medication}

$\square$ Heart medicine

$\square$ Blood pressure medicine

$\square$ Blood cholesterol medicine

$\square$ Hormones

$\square$ Birth control medicine

$\square$ Medicine for breathing/lungs

$\square$ Insulin

$\square$ Other medicine for diabetes

$\square$ Arthritis medicine

$\square$ Medicine for depression

$\square$ Medicine for anxiety

$\square$ Thyroid medicine

$\square$ Medicine for ulcers

$\square$ Painkiller medicine

$\square$ Allergy medicine

$\square$ Other (please specify)

$\square$ Do you have any drug allergies?

$\square$ Dietary supplements (please specify)

\section{Name of Medication}
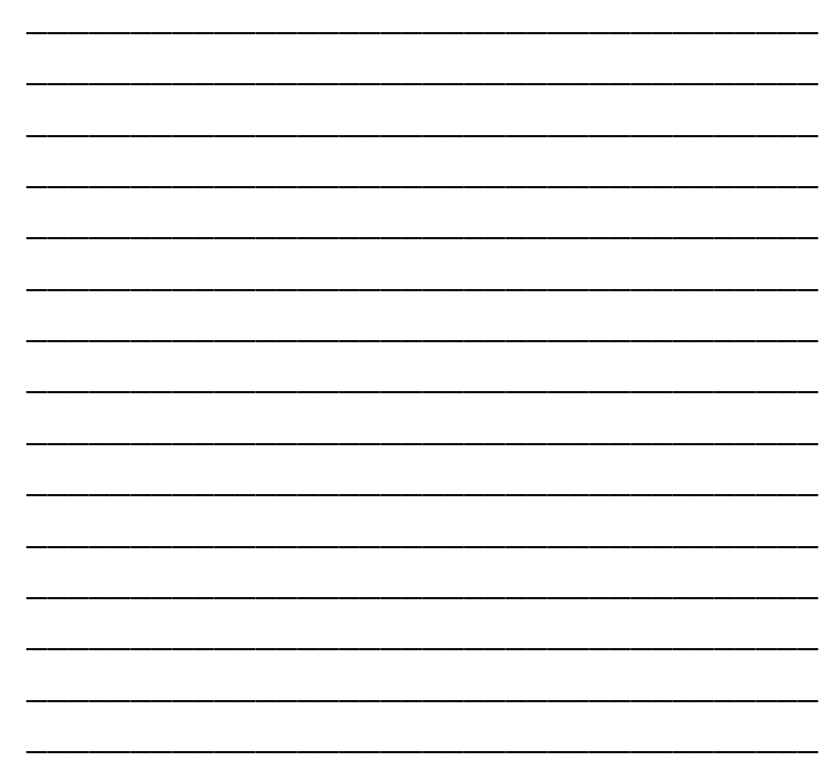

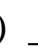

\section{Body Weight}

23. What is the most you have ever weighed? pounds

24. Are you now trying to:

$\square$ Lose weight $\quad \square$ Gain weight $\quad \square$ Stay about the same $\quad \square$ Not trying to do anything

\section{Stress}


25. During the past month, how would you rate your overall level of stress?

$\square$ Very high $\quad \square$ High $\quad \square$ Moderate $\quad \square$ Low

26. In the past year, how much effect has stress had on your health?

$\square$ A lot $\quad \square$ Some $\quad \square$ Hardly any or none

27. On average, how many hours of sleep do you get in a 24-hour period?

$\square$ Less than $5 \quad \square$ 5-6.9 $\quad \square$ 7-9 $\quad \square$ More than 9

\section{Substance Use}

28. How would you describe your cigarette smoking habits?

$\square$ Never smoked

Used to smoke. How many years has it been since you smoked?

years

Still smoke. How many cigarettes a day do you smoke on average?

cigarettes/day

29. How many alcoholic drinks do you consume? (A "drink" is a glass of wine, a wine cooler, a $16 \mathrm{oz}$ bottle/12oz can of beer, a shot glass of liquor, or a mixed drink).
$\square$ Never use alcohol
$\square$ Less than 1 per week
1-6 per week
$\square 1$ per day
$\square$ 2-3 per day
$\square$ More than 3 per day

30. In one sitting, how many drinks do you typically consume?

31. How many cups (8 ounces) of coffee do you drink per day?

32. How many ounces of sodas containing caffeine do you drink per day?

Physical Fitness, Physical Activity/Exercise

33. Considering a 7-Day period (a week), how many times on the average do you do the following kinds of exercise for more than $\mathbf{1 5}$ minutes during your free time (write on each line the appropriate number).

\section{a) STRENUOUS EXERCISE (HEART BEATS RAPIDLY) Week}

(i.e. running, jogging, hockey, football, soccer, squash, basketball, cross country skiing, judo, roller skating, vigorous swimming, vigorous long distance bicycling)

b) MODERATE EXERCISE (NOT EXHAUSTING)

(i.e. fast walking, baseball, tennis, easy bicycling, volleyball, badminton, easy swimming, alpine skiing, popular and folk dancing)

c) MILD EXERCISE (MINIMAL EFFORT)

(i.e. yoga, archery, fishing from river bank, bowling, horseshoes, golf, snow-mobiling, easy walking) 
34. Considering a 7-Day period (a week), during your leisure-time, how often do you engage in any regular activity long enough to work up a sweat (heart beats rapidly)

$\square$ OFTEN $\quad \square$ SOMETIMES $\square$ NEVER/RARELY

35. How long have you exercised or played sports regularly?

$\square$ I do not exercise regularly $\square$ Less than 1 year $\square$ 1-2 years

$\square 2-5$ years $\quad \square$ 5-10 years $\quad \square$ More than 10 years

\section{Occupational Health}

36. Please describe your main job title and duties.

37. How much hard physical work is required on your job?

$\square$ A great deal $\quad \square$ A moderate amount $\quad \square$ A little

None

38. Please list any injuries or surgeries you have or have experienced to your forearms and wrists?

39. Do you currently experience any pain or discomfort in your forearms or wrists? 


\section{References}

1. Achten J, Jeukendrup AE. Heart rate monitoring: Applications and Limitations. Sports Medicine. 33: 517-538, 2003.

2. Allen J, Murray A. Effect of filtering on multi-site photoplethysmorgraphy pulse waveform characteristics. Comp. in Cardiol. 31: 485-488, 2004

3. Allen J. Photoplethysmography and its application in clinical physiological measurement. Physiol Meas. 28: 1-39, 2007.

4. Barbosa VA, Thais LF, Vitto MF, Cesconetto PA, Marques SO, Souza DR, Bom K, Pimentel GD, Katashima CK, Ropelle ER, Pinho RA, Souza CT. Exercise training plays cardioprotection through the oxidative stress reduction in obese rats submitted to myocardial infarction. Int J of Cardiol. 03: 153-156, 2012

5. Burr RL. Interpretation of normalized spectral heart rate variability indices in sleep research: A critical review. Sleep. 30:913-917, 2007.

6. Challoner AV, Ramsay CA. A photo electric plethsmograph for measurement of cutaneous blood flow. Phys. Med. Biol. Vol 19: 317-328, 1974

7. Ceesay SM, Prentice AM, Day, KC, Murgatroyd PR, Goldberg GR, Scott W, Spurr GB. The use of heart rate monitoring in the estimation of energy expenditure: a validation study using indirect whole body calorimetry. Brit $J$ of Nutr. 61: 175-186, 1989.

8. Cennini G, Arguel J, Aksit K, Arno van Leest. Heart rate monitoring via remote photoplethysmography with motion artifacts reduction. Opt Expr. 18: 4867-4875, 2010.

9. Cui W, Ostrander LE, Lee BY. In vivo reflectance of blood and tissue as a function of light wavelength. IEEE Trans on Biomed Eng. 37: 632-639, 1990.

10. Froelicher V, Jensen D, Genter F, Sullivan M, McKirnan MD, Witztum K, Scharf J, Strong ML, Ashburn W. A randomized trial of exercise training in patients 
with coronary heart disease. JAMA. 252: 1291-1297, 1984.

11. Foster C, Florhaug JA, Franklin J, Gottschall L, Hrovatin LA, Parker S, Doleshal P, Dodge C. A new approach to monitoring exercise training. $J$ of Str and Cond Res. 15:109-115, 2001.

12. Gavarry O, Bernard T, Giacomoni M, Seymat M, Euzet JP, Falgairette G. Continous heart rate monitoring over 1 week in teenagers aged 11-16 years. Eur J of App Phys. 77: 125-132, 1998

13. Gibbons RJ, Balady GJ, Beasley JW, Bricker JT, Duvernoy WF, Froelicher VF, Mark DB, Marwick TH, McCallister BD, Thompson PD, Winters WL, Yanowitz FG. ACC/AHA guidelines for exercise testing. J of Amer Col of Cardiol. 30: 260-315, 1997.

14. Glass SC, Chvala AM. Preferred exertion across three common modes of exercise training. J of Str and Cond Res. 15:474-479, 2001.

15. Loukogeorgakis S, Dawson R, Phillips N, Martyn CN, Greenwald SE. Validation of a device to measure arterial pulse wave velocity by a photoplethysmographic method. Physiol Meas. 23: 581-596, 2002.

16. Hagblad J, Lindberg LG, Andersson AK, Bergstrand S, Lindgren M, Ek AC, Folke M, Linden M. A technique based on laser doppler flowmetry and photoplethysmography for simultaneously monitoring blood flow at different tissue depths. Med. Biol. Eng. Comput. 48: 415-422, 2010.

17. Hautala AJ, Makikallio TH, Kiviniemi A, Laukkanen RT, Nissila S, Huikuri HV, Tulppo MP. Heart rate dynamics after controlled training followed by a home based exercise program. Eur J of App Phys. 92: 289-297, 2004.

18. Hjalmarson A, Gilpin EA, Kjekshus J, Schieman G, Nicod P, Henning H, Ross J. Influence of heart rate on mortality after acute myocardial infarction. Amer $J$ of Cardiol. 65: 547-553, 1990.

19. Johansson HP, Rossander-Hulthen L, Slinde F, Ekblom B. Accelerometry combined with heart rate telemetry in the assessment of total energy expenditure. 
Brit J of Nutr. 95: 631-639, 2006.

20. Kamal AA, Harness JB, Irving G, Mearns AJ. Skin photoplethysmography - a review. Comp Meth and Prog in Biomed. 28: 257-269, 1989

21. King AC, Taylor CB, Haskell WL, Debusk RF. Strategies for increasing early adherence to and long term maintenance of home based exercise training in healthy middle aged men and women. Amer J of Cardiol 61: 628-632, 1988

22. Kleiger RE, Miller JP, Bigger T, Moss AJ. Decreased heart rate variability and its association with increased mortality after acute myocardial infarction. Amer $J$ of Cardiol. 59: 256-262, 1987.

23. Lee C, Shin HS, Lee M. Relations between ac-dc components and optical path length in photoplethysmography. J of Biomed Opt. 16: 1-5, 2011.

24. Li R, Deurenberg P, Hautvast JG. A critical evaluation of heart rate monitoring to assess energy expenditure in individuals. Amer J of Clin Nutr. 58: 602-607, 1993.

25. Linder SP, Wendelken S, Clayman J, Steiner PR. Noninvasive detection of the hemodynamic stress of exercise using the photoplethysmogram. J of Clin Monit and Comp. 22: 269-278, 2008.

26. Maeda Y, Tamura ST, Moriya A, Suzuki T, Kameyama K. Comparison of reflected green light and infrared photoplethysmography. IEEE Conference, August 20-24, 2008.

27. Mazzero RS, Tanaka H. Exercise prescription for the elderly. Sports Med. 31: 809-818, 2001.

28. McCombie DB, Reisner AT, Asada HH. Adaptive blood pressure estimation from wearable PPG sensors using peripheral artery pulse wave velocity measurements and mutli-channel blind identification of local arterial dynamics. IEEE Conference, August 6-September 3, 2006.

29. McCory MA, Mole PA, Nommsen-Rivers LA, Dewek KG. Between day and within day variability in the relation between heart rate and oxygen consumption: effect on the estimation of energy expenditure by heart rate monitoring. Amer $J$ of 
Clin Nutr. 66: 18-25, 1997.

30. McManus AM, Masters RSW, Laukkanen RM, Yu CC, Sit C, Ling CM. Using heart-rate feedback to increase physical activity in children. Prev Med. 47: 402408, 2008.

31. Mendelson Y, McGinn MJ. Skin reflectance pulse oximetry: In vivo measurements from the forearm and calf. J of Clin Monit. 7: 7-12, 1991.

32. Mendelson Y, Ochs BD. Noninvasive pulse oximetry utilitzing skin reflectance photoplethysmography. IEEE Trans on Biomed Eng. 35: 1-10, 1988.

33. Meglinski IV, Matcher SJ. Quantitative assessment of skin layers absorption and skin reflectance spectra simulation in the visible and near-infrared spectral regions. Physiol Meas. 23: 741-753, 2002.

34. Montgomery PG, Green DJ, Etxebarria N, Pyne DB, Saunders PU, Minahan CL. Validation of heart rate monitor-based predictions of oxygen uptake and energy expenditure. J of Str and Cond Res. 23: 1489-1495, 2009.

35. Moon JK, Butte NF. Combined heart rate and activity improve estimates of oxygen consumption and carbon dioxide production rates. J of App Phys. 81: 1754-1761, 1996.

36. Muraoka MY, Carlson JG, Chemtob CM. Twenty-four-hour ambulatory blood pressure and heart rate monitoring in combat-related posttraumatic stress disorder. J of Trau Str. 11: 473-484, 1998.

37. Ogawa T, Spina RJ, Martin WH, Kohrt WM, Schechtman KB, Holloszy JO, Ehsani AA. Effects of aging, sex, and physical training on cardiovascular responses to exercise. Circ. 86: 494-503, 1992.

38. Opthof T, Coronel R. The normal range and determinants of the intrinsic heart rate in man. Cardio Res. 45: 175-176, 2000.

39. Ring-Dimitriou S, Duvillard SP, Stadlmann M, Kinnunen H, Drachta O, Muller E, Laukkanen R, Hamra J, Weeks S, Peak K. Changes in physical fitness in moderately fit adults with and without the use of exercise telemetry monitors. 
Euro J of App Phys. 102: 505-513, 2008.

40. Sandberg M, Zhang Q, Styf J, Gerdle B, Lindberg LG. Non-invasive monitoring of muscle blood perfusion by photoplethysmography: evaluation of a new application. Acta Phys Scan. 183: 335-343, 2005.

41. Seals DR, DeSouza CA, Donato AJ, Tanaka H. Habitual exercise and arterial aging. J of App Phys. 105: 1323-1332, 2008.

42. Seals DR, Hagberg JM, Hurley BF, Ehsani AA, Holloszy JO. Endurance training in older men and women 1. Cardiovascular responses to exercise. $J$ of App Phys. 57: 1024-1029, 1984.

43. Stojanovic R, Karadaglic D. A LED-LED based photoplethysmography sensor. Physiol Meas. 28: 19-27, 2007.

44. Stratonnikov AA, Loschenov VB. Evaluation of blood oxygen saturation in vivo from diffuse reflectance spectra. J of Biomed Opt. 6: 457-467, 2001.

45. Stratton JR, Levy WC, Cerquira MD, Schwartz RS, Abrass IB. Cardiovascular responses to exercise. Effects of aging and exercise training in healthy men. Circ. 89: 1648-1655, 1994.

46. Tanaka G, Yamakoshi K, Sawada Y, Matsumura K, Maeda K, Kato Y, Horiguchi $\mathrm{M}$, Ohguro $\mathrm{H}$. A novel photoplethysmography technique to derive normalized arterial stiffness as a blood pressure independent measure in finger vascular bed. Physiol Meas. 32: 1869-1883, 2011.

47. Tanaka H, Monahan KD, Seals DR. Age-predicted maximal heart rate revised. $J$ of Amer Col of Cardiol. 37: 153-156, 2001.

48. Treuth MS, Adolph AL, Butte NF. Energy expenditure in children predicted from heart rate and activity calibrated against respiration calorimetry. Amer J of Phys Metab. 275: 12-18, 1998.

49. Weinman J, Hayat A, Raviv G. Reflection photoplethysmography of arterialblood volume pulses. Med. And Biol. Eng. And Comput. 15:22-31, 1977. 
50. Zonios G, Bykowski J, Kollias N. Skin melanin, hemoglobin, and light scattering properties can be quantitatively assessed in vivo using diffuse reflecatance spectroscopy. J of Invest Derm. 117: 1452-1457, 2001. 